Available Online at https://journal.unismuh.ac.id/index.php/otoritas

Otoritas : Jurnal Ilmu Pemerintahan, 11 (1), April 2021, 45-53

\title{
Towards the Collaborative Governance in Maintaining Indigenous History of Pejangki Village in Indragiri Hulu, Indonesia
}

\author{
Raja Muhammad Amin ${ }^{1}$, Auradian Marta ${ }^{*}$ ) \\ ${ }_{1}^{1}$ Department of Government Studies, Faculty of Social and Political Sciences, Universitas Riau, \\ Jl. HR. Soebrantas Km. 12,5 Pekanbaru, 28293, Indonesia.
}

Received: 14 January 2020; Revised: 11 March 2021; Accepted: 28 April 2021

\begin{abstract}
Pejangki Village is one of the villages that has managed to maintain its long-standing indigenous history. The argument from this study is that success in preserving indigenous history is the result of a multi-actor collaboration process within it. Therefore, this study seeks to explore collaboration among actors in maintaining indigenous history in Pejangki Village, Batang Cenaku District, Indragiri Hulu Regency, Riau Province. This study uses a qualitative approach with a focus on analyzing collaboration between state and non-state actors in the context of maintaining indigenous history in Pejangki Village. The data obtained were sourced from interviews and secondary data which included report results, journals, documents, and minutes of meetings. The results of this study indicate that collaboration among these actors can be successful because of the initial conditions that support collaboration, institutional design, multi-stakeholder participation and engagement, and facilitative leadership. The conclusion is that the policy of maintaining indigenous history in Pejangki Village is the result of the practice of collaborative governance carried out by state and non-state actors.
\end{abstract}

Keywords: Collaborative Governance; Indigenous History; Pejangki Village

How to Cite: Amin, R. M., \& Marta, A. (2021). Towards the Collaborative Governance in Maintaining Indigenous History of Pejangki Village in Indragiri Hulu, Indonesia. Otoritas : Jurnal Ilmu Pemerintahan, 11(1), 45-53.

Permalink/DOI: https://doi.org/10.26618/ojip.v11i1.3002

${ }^{*}$ Corresponding Author.

E-Mail : auradian_unri@yahoo.com

Copyright (C) 2021, Otoritas : Jurnal Ilmu Pemerintahan, ISSN: 2088-3706 (Print), ISSN: 2502-9320 (Online) 


\section{INTRODUCTION}

This study tries to explain interaction and collaboration among actors in the effort of maintaining customs in Pejangki Village, Indragiri Hulu Regency, Riau Province. The terminology of customs according to Davidson \& Henley (2007) used is simply to refer to particular time-honoured practices and institutions, inherited by communities rather than imposed by the state, which are seen as having continuing relevance to current political concerns. Furthermore, it was stated that there are 3 (three) fundamental things related to customs, which are (1) history; (2) land; and (3) law.

The importance of these customs is responsibility and authority of the village. This is according to the Article 18 of Law number 6 of 2014 about Village which confirms, village authority includes authority in the area of implementation of Village Government, implementation of Village Development, development of Village communities, and empowerment of Village communities based on community initiatives, original rights, and Village customs.

Therefore, customs which are owned by village that must be maintained and preserved. This also applies to Pejangki Village in Indragiri Hulu Regency, which has succeeded in maintaining and preserving its indigenous history. The recognition of indigenous history in Pejangki Village is evidenced by registration of its indigenous territory by the Indigenous Territory Registration Agency on August 19, 2015.

Research on customs in Indonesia has generally been carried out by bachelors with various perspectives and focus studies, such as analyzing indigenous rights (McWilliam, 2006; Tyson, 2011; and Rachman, 2014), exploring indigenous law (Abubakar, 2013; Alting, 2011; Irianto, 2004; and von Benda-Beckmann, 2011), and indigenous community con- flict (Duncan, 2009; Mutolib et al., 2015; and Suharko, 2016).

Meanwhile, the difference in this study focuses on interaction and collaboration among actors in maintaining customs in Pejangki Village. The argument from this study is that success of maintaining customs in Pejangki Village is the result of collaborative governance. The collaborative governance according to Ansell and Gash (2007) refers to a governing arrangement where one or more public agencies directly engage non-state stakeholders in a collective decision-making process that is formal, consensusoriented, and deliberative a nd that aims to make or implement public policy or manage public programs or assets.

Therefore, it is interesting to analyze how interaction and collaboration of state actors and stakeholders in the effort of maintaining indigenous history in Pejangki Village, Indragiri Hulu Regency. Maintaining customs for indigenous community is as important as maintaining pride. Then, customs in indigenous community need to be recognized by the state, so their existence can be maintained. Based on that empirical phenomenon, this study tries to answer the question that "how is collaboration among actors in maintaining indigenous history in Pejangki Village, Batang Cenaku District, Indragiri Hulu Regency, Riau Province?". This study has contributed to development of collaborative governance, especially in local context. Although this study is in local context, actors involved in process of maintaining customs in Pejangki Village are multi-stakeholders.

\section{RESEARCH METHODS}

This study uses a qualitative method with a phenomenological approach. Phenomenological research is a design of inquiry coming from philosophy and psychology in which the researcher describes the lived experiences of individuals about a phenomenon as described by partici- 
pants. This description culminates in the essence of the experiences for several individuals who have all experienced the phenomenon (Creswell, 2014). The data needed in this study are primary data and secondary data. Primary data are obtained by in-depth interview with research informant in obtaining information about collaboration among actors in maintaining customs in Pejangki Village, Indragiri Hulu Regency. These primary data are obtained from research informant which is determined by purposive technique such as the Government of Pejangki Village element, Non-Governmental Organization (NGO) (such as the Archipelago Indigenous Community Alliance), traditional leader, and the Government of Indragiri Hulu Regency element. Then, the secondary data needed in this study come from minutes of meetings, photo documentations, reports, and news related to research issues.

Primary data collection in this study was used through interview method. Data collection technique uses interview method which involves various sides by expecting verbal responses (Kothari, 2004). This interview method can be used through personal interview and possibilty also uses telephone interview. Personal interview is carried out by face to face contact with research informant as a form of direct investigation by writing and recording all information or data obtained. The form of question in this personal interview is carried out openly, so the informant can explore answers from each question asked.

Meanwhile, for secondary data collection, documentation technique can be used through published data. The documentation technique was obtained from report data from the Government of Indragiri Hulu Regency, publication from Non-Governmental Organization (NGO), journal, book, magazine, newspaper, online news, statistical record, and research reports. The complexity of data sourced from this documentation will be complementary to data from in-depth interview with research informant.

Data collected both from interview and document data from research informant will be condensed and displayed. This data condensation refers to the process of selecting, focusing, simplifying, abstracting, and/or changing data from field note, interview transcript, document and other empirical documents. The next activity flow is displaying data which mean to assemble the information and to display it systematically. The collection of data collected, selected and displayed systematically and organizly is useful for further activity in data analysis that is verifying and describing data with interpretation based on theory used. Finally, researcher makes conclusion from the stages that have been passed (Miles, Huberman, \& Saldaña 2014).

\section{RESULTS AND DISCUSSION}

Identification of indigenous territory in Pejangki Village has been started since 2013 as a form of commitment to resolution and edict of the Gawai Gedang Talang Mamak indigenous community. The participatory mapping of indigenous territory involved various parties that are the Archipelago Indigenous Community Alliance of Indragiri Hulu, the Archipelago Indigenous Community Alliance of Riau, the Participatory Mapping Work Network, the Samdhana Institute, village government, and district government. The indigenous territory in Pejangki Village has recorded a total of 7,943 hectares and has been registered by the the Indigenous Territory Registration Agency on August 19, 2015.

The mapping of indigenous territory in Pejangki Village is a form of protection to indigenous history and also protection to economic resources of indigenous community livelihood from various threats, especially from company and corporate interests. The indigenous lands and for- 
ests in Indragiri Hulu Regency have been overally controlled by corporation with permit issued by the Government. Research from Dewi (2017) shows that the Talang Mamak indigenous community efforts to maintain its customs by gathering oral and written traditions, but the efforted in restoring its constitutional rights are hampered by government permissions to company and corporation in there.

Furthermore, in protecting indigenous territory and forest sustainibilty in Pejangki Village, collaboration is also carried out with the Bukit Tiga Puluh National Park. This collaboration is carried out because indigenous territory in Pejangki Village is directly bordering to the TNBT territory. The socialization of boundary in the TNBT territory with Pejangki Village was carried out to create synergy between the village community, the government of village, and the TNBT side. This socialization of territory boundary was carried out on July 19, 2018 in Pejangki Village.

Indigenous territory in Pejangki Village also borders to the territory of Siambul Village, so their village map is made based on a historical letter. Therefore, the Government of Pejangki Village, the Government of Simbul Village, and traditional leaders in the two villages held a meeting to discuss indigenous territory border based on historical letter and information sourced from parents. The result of boundary mapping is conveyed to the Regent of Indragiri Hulu. The making of history and village maps also aims to avoid inter-village conflicts because of unclear boundary.

Meanwhile, the customs values that are still alive and thriving in Pejangki Village are the validity of indigenous institutions in Pejangki Village. Pejangki Village is traditionally called by Kebatinan Pejangki which is led by the Batin and administratively led by the Village Head. Batin is a traditional leader who has au- tonomous rights over indigenous territory, indigenous institution and indigenous arrangement. Formerly, village head and Batin were the same person, but because of the dynamic of change in national regulation by the formation of Law number 5 of 1979 about Village Government results the uniformity of village terms and eliminates the indigenous characteristics in village.

Therefore, in preserving customs in Pejangki Village, indigenous history was made involving indigenous elements, which are the Batin of Pejangki, the Mangku Adat, the Batin of Muko-Muko, the Batin of Pembumbung, the Batin of Pemuncak, the Batin of Beligan, the Patih, and the Village Head of Pejangki. Meanwhile, the Head of Batang Cenaku District as a representative of the Regional Government of Indragiri Hulu Regency has involved in the making process of indigenous history in Pejangki Village. Finally, on March 13, 2017 the map and history of Pejangki Village were endorsed by Village Government that was be subsequently given to the Regent of Indragiri Hulu in using policy material recognized as indigenous community unit.

Furthermore, a collaborative process between state and non-state actors has taken place to support the maintaining customs in Pejangki Village. However, there are still shortcomings in the collaboration process that is not yet involving the private sector. The role of private sector such as company and corporation is needed in collaborative governance. According to Donahue \& Zeckhauser (2011) is stated that the role of the private sector is needed in achieving public goals. This is due to the private sector has the resource needed by the government in overcoming public problems.

However, support from the private sector for effort in maintaining customs in Pejangki Village is still weak. The private sector has not participate in the discussion of indigenous history in Pejangki Vil- 
Available Online at https://journal.unismuh.ac.id/index.php/otoritas

Otoritas : Jurnal Ilmu Pemerintahan, 11 (1), April 2021, 49

lage, even though the village government had asked assistance and participation from the private sector. The different interest between company with corporation and indigenous community in Pejangki Village have made collaboration among these actors unable worked. The private sector has an interest in defending its land and indigenous community want land and forest as part of its indigenous history back, which has been controlled by company and corporation.

Ansell \& Gash (2007) states that institutional design plays an important role in collaborative processed. This institutional design can be explained by transparency and active participation of all stakeholders in maintaining indigenous history in Pejangki Village. The principle of openness is carried out in establishing relationship, so each actor is characterized by communicative decision making, that is process of dialogical leading to constructive results. Innes \& Booher (2010) states that the dialogue carried out in the collaborative process must be authentic dialogue, not rhetorical or formality. Meanwhile, Denhardt and Denhardt (2007) argued that a necessity sees the important position of institution and community organization as owner of government and it is able to act together in struggling for greater good; striving for shared values and public interest through widespread dialogue and involvement of all community components.

This dialogue process is carried out in meeting forum which held in village level to regency level. The village level meeting involving all village components

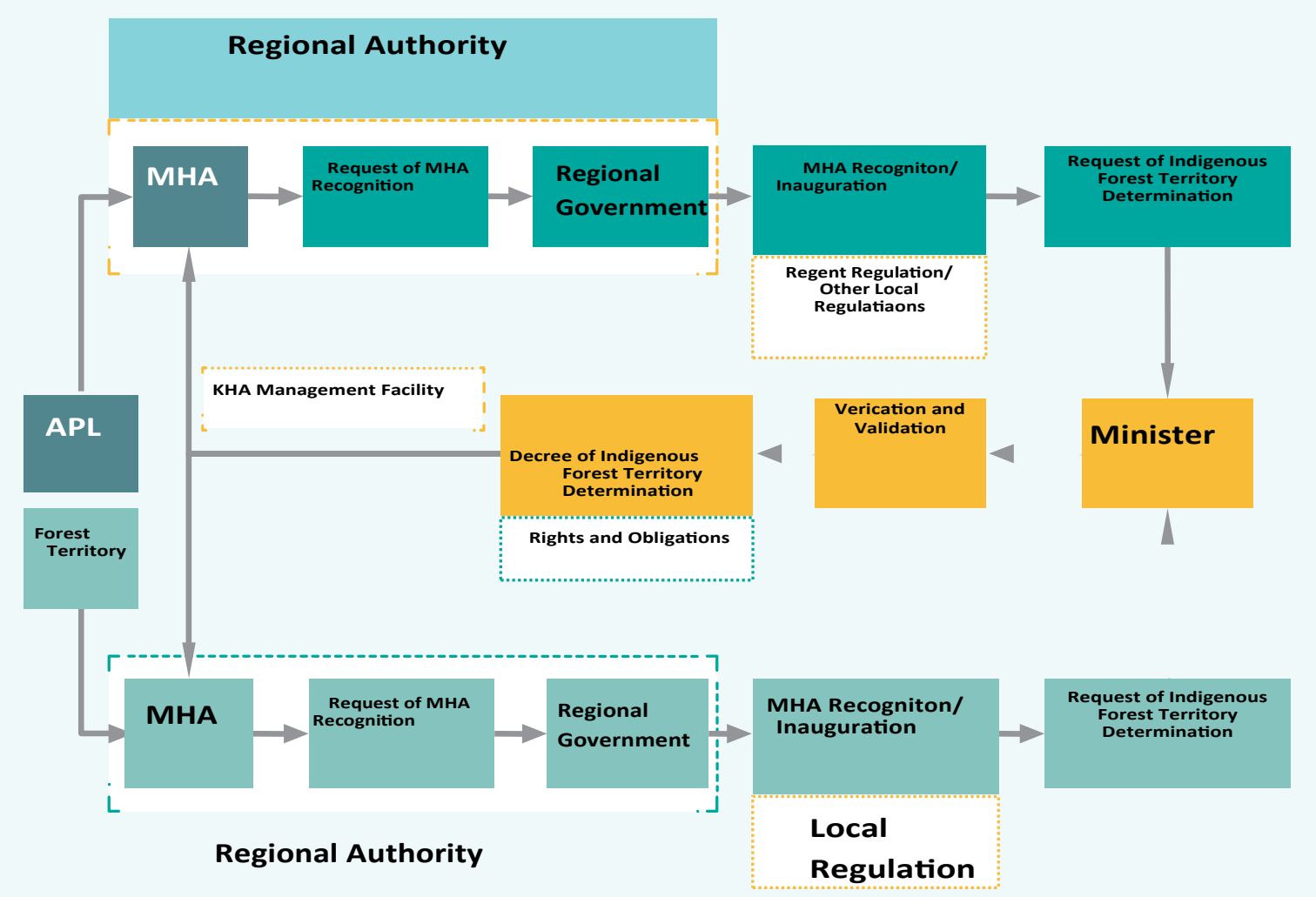

Figure 1. The Inauguration Process of Indigenous Community and Indigenous Forest Source: Ministry of Environment and Forestry of Republic Indonesia (2018) 
such as village government apparatu, the Village Consultative Body, youth leader, traditional leader was held to discuss indigenous history in Pejangki Village. Furthermore, a dialogic process also took place in the regency level in advocating recognition policy and in protecting indigenous community in Pejangki Village.

Furthermore, the influence of regulation at national level also determines the dynamics of collaboration in maintaining customs in Pejangki Village. The regulation is the Constitutional Court Decision number 35 of 2012 about testing of the Forestry Law and Regulation of the Minister of Home Affairs number 52 of 2014 about Guideline for the Recognition and Protection of Indigenous Community. The existence of this regulation makes the sprit to indigenous community in maintaining indigenous history, especially in increasing indigenous land and forest at the local level.

The issuance of the Constitutional
Court policy number 35 of 2012 which recognizes existence of indigenous forest as rights forest. It provides hope for indigenous people so their constitutional rights are recognized by the state. However, in order to be recognized by the state, so the forest and indigenous territory must be recommended in local policy such as Regional Regulations or Regent Regulations. More clearly, the flow of recognition procedure of indigenous community and indigenous forest can be displayed at the figure 1 .

Based on the picture above, it can be explained that the role of regional government is so important in giving recognition to indigenous community because the result of policy will be forwarded to the Government through the Minister to be determined as indigenous community and recognition of its rights. However, the process of forming this policy for recognition and protection in Pejangki Village is still stuck in the Regional Government of
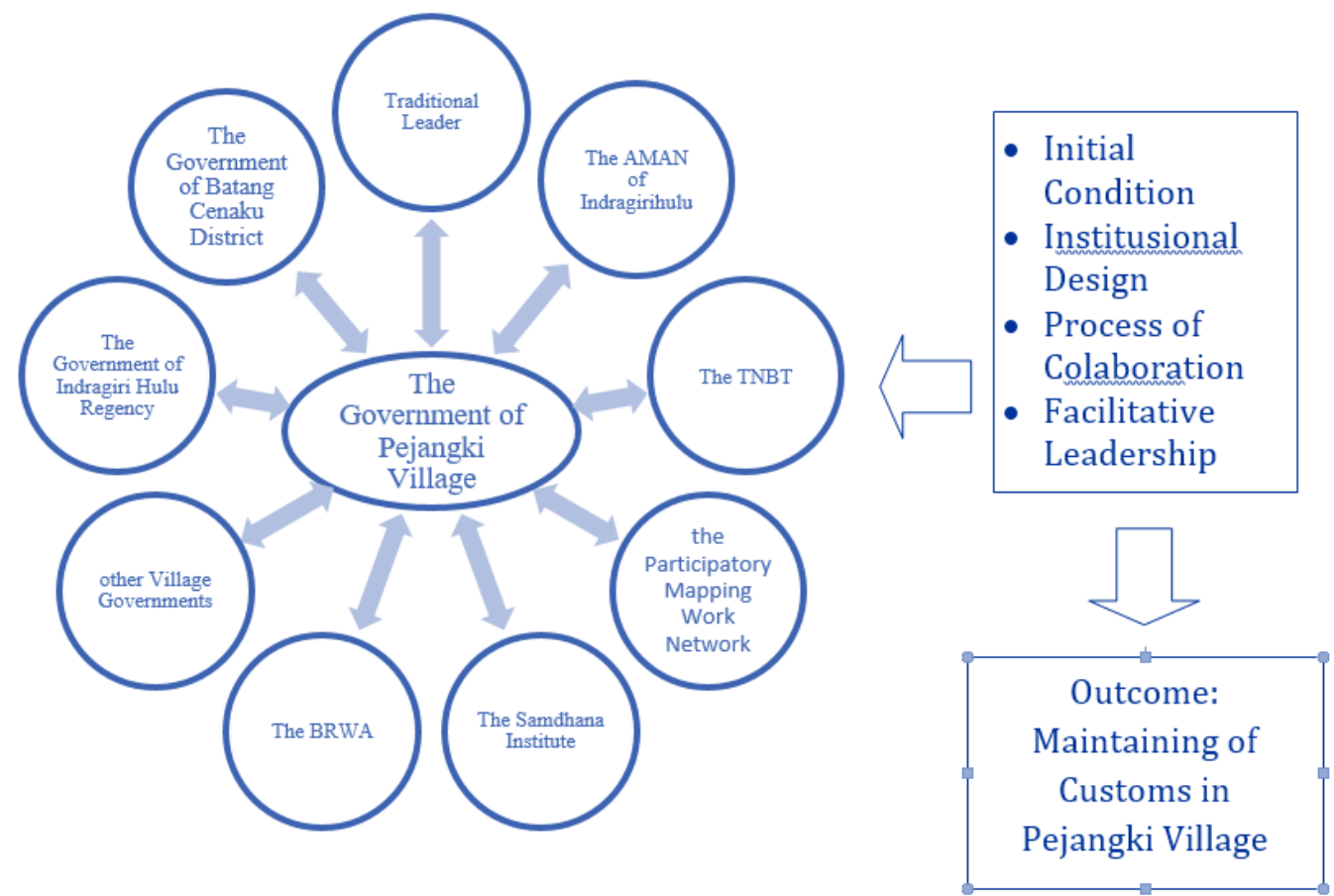

Figure 2. The Collaborative Governance Model in Maintaining Indigenous History in Pejangki Village Source: Processed by the Authors (2019) 
Indragiri Hulu Regency.

The leadership factor is needed so collaboration and synergy among actors run well. The head of Pejangki Village has an important role in the collaborative process because of the initiative in maintaining customs in the village. The facilitative leadership character is seen by the Head of Pejangki Village involving various actors in collecting oral and written indigenous history with the internal actors in Pejangki Village, other village indigenous leaders, the Government of Indragiri Hulu Regency, TNBT, and NGOs.

The purpose of active involvement and participation by the village government, traditional leader, local government actor of Indragiri Hulu Regency and NGOs is that the result of decision or policy can be accepted by all sides. The Village Head acts as a facilitator by delegating authority to individual and institution that have competence in order to support the goal achievement in maintaining customs in Pejangki Village. Crosby \& Bryson (2005) in Svara (2009) argue that in leadership, there is a division of authority so leader in this situation inspire and motivate follower through persuasive and empowering action, not through command or control. Furthermore, the leader encourages dialogue and collective action to overcome shared problems.

In this regard, the distribution of authority carried out in maintaining customs in the Pejangki Village is fully given authority to the traditional leader to decide boundaries territory and indigenous history existed. Then, for the mapping of indigenous territory is handed over to NGOs who have the capability for it, but the mapping process is carried out with parcipatory involving the traditional leaders in Pejangki Village and other traditional leaders in the village.

Therefore, based on fact and finding from the field, the collaborative governance model in maintaining indigenous history in Pejangki Village can be ex- plained in the figure 2 .

\section{CONCLUSION}

The policy in maintaining customs in Pejangki Village is the result of colloborative governance that is the collaboration of state and non-state actors. Colloborative governance model is very relevant in the process of maintaining customs in $\mathrm{Pe}-$ jangki Village because it requires the participation of various stakeholders. Stakeholders in this case are state actors represented by Government of Pejangki Village and Government of Indragiri Hulu Regency. Meanwhile, non-state actors also play a role in maintaining the customs represented by traditional leader, indigenous community, traditional institution, and NGOs. Collaboration among actors in maintaining these customs can be successful because of the initial condition in Pejangki Village that supports the collaboration process which the existence of resources such as traditional leader who has knowledge of indigenous history. Furthermore, indigenous law and indigenous institution still regulate the lives of indigenous community in Penjangki Village.

The collaborative process in maintaining customs in Pejangki Village can be successful because of the participation and involvement of various sides with the principles of openness, equality, clear rule, and facilitative leadership. However, the role of the private sector is still weak in maintaining customs in Pejangki Village because of the interest of company and corporation that are contradictory to the interest of indigenous community.

\section{ACKNOWLEDGEMENT}

Thank you to the Faculty of Social and Political Sciences, Universitas Riau for funding this research in PNBP 2019.

\section{REFERENCES}

Abubakar, L. (2013). Revitalisasi Hukum Adat sebagai Sumber Hukum dalam 
Available Online at https://journal.unismuh.ac.id/index.php/otoritas

Otoritas : Jurnal Ilmu Pemerintahan, 11 (1), April 2021, 52

Membangun Sistem Hukum Indonesia. Jurnal Dinamika Hukum, 13(2).

Alting, H. (2011). Penguasaan Tanah Masyarakat Hukum Adat (Suatu Kajian terhadap Masyarakat Hukum Adat Ternate). Jurnal Dinamika Hukum, 11(1).

Ansell, C., \& Gash, A. (2007). Collaborative governance in theory and practice. Journal of public administration research and theory, 18(4), 543-571.

Chhotray, V., \& Stoker, G. (2009). Governance theory and practice: $A$ cross-disciplinary approach. London: Palgrave Macmillan.

Creswell, John W.(2014). Research design : qualitative, quantitative, and mixed methods approaches 4th ed. Los Angeles, London. New Delhi, Singapore, Washington DC: SAGE Publications

Davidson, J., \& Henley, D. (Eds.). (2007). The revival of tradition in Indonesian politics: The deployment of adat from colonialism to indigenism. London: Routledge.

Denhardt, J.V., \&. Denhardt, R.B. (2007). The New Public Service: Serving, Not Steering. New York: M.E. Sharpe.

Dewi, A.R. (Ed). (2017). Persoalan Agraria Kontemporer: Teknologi, Pemetaan, Penilaian Tanah, dan Konflik. Yogyakarta: Pusat Penelitian dan Pengabdian kepada Masyarakat (PPPM) dan STPN Press.

Donahue, J. D., \& Zeckhauser, R. J. (2011). Collaborative governance: Private roles for public goals in turbulent times. New Jersey: Princeton University Press.
Duncan, C. R. (2009). Reconciliation and revitalization: the resurgence of tradition in postconflict Tobelo, North Maluku, Eastern Indonesia. The Journal of Asian Studies, 68(4), 1077-1104.

Emerson, K., \& Nabatchi, T. (2015). Collaborative governance regimes. Washington: Georgetown University Press.

Emerson, K., Nabatchi, T,. \& Balogh, S. (2011) An integrative framework for collaborative governance. Journal of Public Administration Research and Theory, 22(1), 1-29.

Hadiwijoyo, S.S. (2012). Negara, Demokrasi, dan Civil Society. Yogyakarta: Graha Ilmu.

Hamidy, UU. (2014). Jagad Melayu dalam Lintasan Budaya di Riau. Pekanbaru: Bilik Kreatif Press.

Innes, J.E. \& Booher, D.E. (2000) Collaborative Dialogue as a Policy Making Strategy. Institute of Urban and Regional Development University of California, Berkeley. IURDWorking Paper.

Irianto, S. (2004). Competition and Interaction between Stae Law and Customary Law in the Court Room: a study of inheritance cases in Indonesiat. The Journal of Legal Pluralism and Unofficial Law, 36(05).

Kementerian Lingkungan Hidup dan Kehutanan. (2018). Status Hutan \& Kehutanan Indonesia 2018. Jakarta: Kementerian Lingkungan Hidup dan Kehutanan,

Kooiman, J. (2003). Governing as governance. California: SAGE.

Kothari, $\quad$ C. $\quad$ R. (2004). Research 
Available Online at https://journal.unismuh.ac.id/index.php/otoritas

Otoritas : Jurnal Ilmu Pemerintahan, 11 (1), April 2021, 53

methodology: Methods and techniques. New Delhi: New Age International.

McWilliam, A. (2006). Historical reflections on customary land rights in Indonesia. The Asia Pacific Journal of Anthropology, 7(1), 4564.

Miles, M. B., Huberman, A. M., \& Saldana, J. (2014). Qualitative data analysis: $A$ method sourcebook. CA, US: Sage Publications.

Mutolib, A., Yonariza, Y., Mahdi, M., \& Ismono, H. (2015). Konflik agraria dan pelepasan tanah ulayat (Studi kasus pada masyarakat suku melayu di Kesatuan Pemangkuan Hutan Dharmasraya, Sumatera Barat). Jurnal penelitian sosial dan ekonomi kehutanan, 12(3).

Rachman, N. F. (2014). Masyarakat Hukum Adat Adalah Bukan Penyandang Hak, Bukan Subjek
Hukum, dan Bukan Pemilik Wilayah Adatnya. Wacana, 33, 25-50.

Suharko, S. (2016). Masyarakat Adat versus Korporasi: Konflik Sosial Rencana Pembangunan Pabrik Semen di Kabupaten Pati Jawa Tengah Periode 2013-2016. Jurnal Ilmu Sosial dan Ilmu Politik, 20(2).

Svara, J. H. (Ed.). (2009). The facilitative leader in city hall: Reexamining the scope and contributions. Florida: CRC Press.

Tyson, A. (2011). Being special, becoming indigenous: Dilemmas of special adat rights in Indonesia. Asian Journal of Social Science, 39(1).

von Benda-Beckmann, F., \& von BendaBeckmann, K. (2011). Myths and stereotypes about adat law: A reassessment of Van Vollenhoven in the light of current struggles over adat law in Indonesia. Bijdragen tot de taal-, land-en volkenkunde/Journal 